\title{
Public and Expert Opinions on Free Trade Agreements in South America
}

\author{
Krzysztof Beck, Bogna Gawrońska-Nowak, Paul Valdivieso
}

\begin{abstract}
A B S T R A C T
Objective: Free Trade Agreements (FTA) have recently drawn public attention due to political populism, alter-globalisation, and tendencies to redefine economic ties, together with the stereotype of mismatching social perception and so-called 'expert knowledge'. Confronting this stereotype may contribute to better understanding of FTA controversies and identify possible vulnerability sources at the policy implementation level.
\end{abstract}

Research Design \& Methods: To analyse FTA impact, meta-analysis of the literature research results was performed using the sample of eight Spanish language papers. We included models in which natural logarithm of a trade measure was regressed on FTA dummy variable with other explanatory variables following Viechtbauer (2010).

Findings: With FTA dummy variable increased trade can have its sources both in trade creation and trade diversion. Also, the endogeneity issue might result in overestimation of the effect, as countries that trade more are more likely to establish a FTA. Weighted least squares fixed effects models at both the study and the model level support this notion. Unweighted least squares models for Spanish language papers are the only ones where the positive effect of FTA is not statistically significant.

Implications \& Recommendations: Spanish language literature gives a lot of support to the notion that FTAs are associated with higher trade. However, the exact size of the effect can be brought to question.

Contribution \& Value Added: Public opinion in South America seems quite supportive for FTA and economic integration. Meta-analysis results confirm positive FTA effects, supporting its use as a convincing argument for further integration.

\begin{tabular}{ll}
\hline Article type: & research article \\
Keywords: & Free Trade Agreements (FTA); meta-analysis; public opinion \\
JEL codes: & F13, F14, F53, F55, Z13
\end{tabular}

Received: 30 August 2018 Revised: 22 January 2019 Accepted: 2 February 2019

\section{Suggested citation:}

Beck, K., Gawrońska-Nowak, B., \& Valdivieso, P. (2019). Public and Expert Opinions on Free Trade Agreements in South America. Entrepreneurial Business and Economics Review, 7(2), 7-25. https://doi.org/10.15678/EBER.2019.070201 


\section{INTRODUCTION}

Recently Free Trade Agreements (FTA) have been drawing public attention being affected enormously by new waves of political populism, alter-globalisation, and some tendencies to redefine patterns of the world economic ties. From the European perspective, especially the Comprehensive Economic and Trade Agreement (CETA), and the Transatlantic Trade and Investment Partnership (TTIP) have brought 'on board' serious public concerns about environmental protection, food quality, job security, and citizen rights. Donald Trump openly criticizes the North American Free Trade Agreement (NAFTA) calling it 'the single worst trade deal ever approved in this (US) country'.

It is interesting to find out if South American public opinion on FTA is affected by similar populist tendencies. There is also quite a common stereotype that there is a mismatch between social perception concerning FTA with the so-called 'expert knowledge'. Defining a mismatch between the social perception and the expert knowledge may contribute to better understanding of the controversies on FTA, as well as to properly defining possible sources of social conflicts and vulnerabilities of the policy at the implementation level. Having examined relevant studies on the social expectations in Europe concerning FTA (for example Bertelsmann Foundation, 2016; Eurobarometer 2014; 2015) one can observed that the analysis should be developed and continued in more detail, including countryspecific and time-variant dimensions.

In our article we have a look at Latinobarómetro results to describe public opinion on FTA in South America and we confront them with so-called 'expert opinions'. To do so we try to confirm in a statistically significant way if there is a key message in the Spanish language expert materials about trade and its effects that the experts could disseminate to the world.

In section 2 we briefly summarise historical evolution of FTA in South America. Section 3 provides us with public opinion on FTA and economic integration. In section 4 we present descriptive analysis of the Spanish language expert databases and methodological approach towards meta-analysis, while section 5 shows its results. Section 6 concludes.

\section{LITERATURE REVIEW}

\section{Free Trade Agreements in the Region: Present and Past}

South America, along with Latin America as a whole, has historic and social conditions that favour integration. The region has multiple homogeneity traits when compared to other world regions. In particular, cultural, linguistic and religious similarities should be highlighted. However, at the same time some political disagreements and periodical instabilities must be considered (Thoene, Zamora, Júnior, \& Londoño, 2017; Shuaibu \& Oladayo, 2016; Crespo Stupková, 2016). Economic growth and poverty reduction require trade, which in turn would only increase with openness and integration occurring in an environment where supportive initiatives ensure that the benefits of trade spill to all the society (WTO, 2015). The region has a long history of integration efforts and trade agreements evolving in line with varying trade policy frameworks. This trend currently continues, even though the focus of the various trade agreements has varied over time together with the political context (Figure 1). 


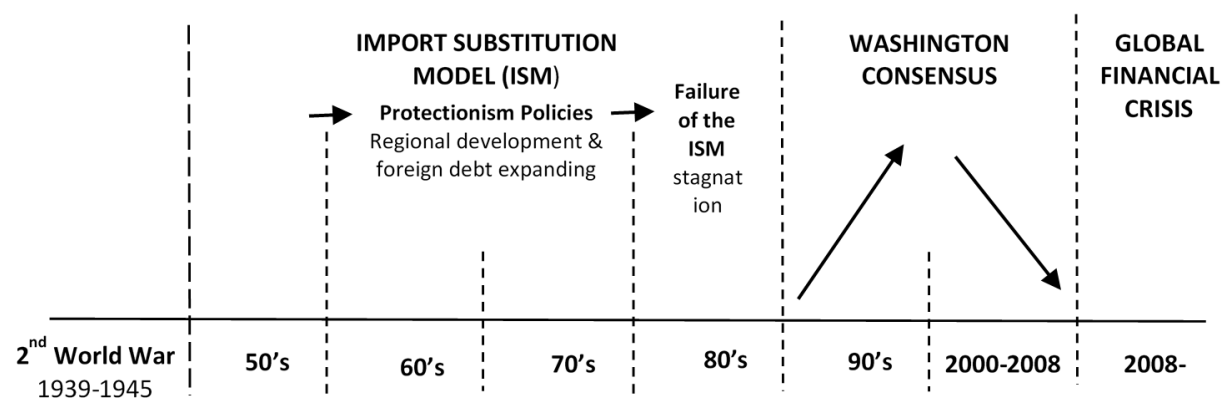

Figure 1. Evolution of trade policy frameworks after the 2 nd World War Source: own elaboration.

After the Second World War, South American countries adhered to the Import Substitution Model (ISM) as a development paradigm set by the United Nations Economic Commission for Latin America and the Caribbean ECLAC (or CELAC in Spanish) which was formed in 1948, in opposition to the United States-led Pan Americanism concept. From then onwards, the South American countries have had a central role in cooperation and regional integration processes (Bermúdez Torres, 2011).

The ISM was aligned to increasing manufacturing in the region together with a diminished level of the European exports. Martínez Rangel and Soto Reyes Garmendia (2012) highlight the evolution of the region's policy framework over the last decades, starting from the ISM with a period that ranges from 1950 to the early 1980's when the governments' role was questioned as the benefits from growth were not perceived by a large proportion of the population. By the end of 1960's and during the 1970's, efforts were focused on regional development through protectionist policies while expanding foreign debt levels to fund the development model. In the 1980's it became quite evident that the model was inoperative reaching a stagnated environment with no economic growth, impending recessions and diminishing debt-servicing capacity for most countries, which led to a number of defaults including the cases of Brazil, Mexico and Argentina. By the end of 1980's the results of the ISM were bleak in South and Latin America, with high public deficit, restricted local financial and foreign exchange markets, goods markets that were closed to world competition, restricted foreign investment, inefficient public firms and multiple labour market constrains.

The Washington Consensus represented an open and liberalised approach with promarket initiatives, limited state intervention and macroeconomic discipline. The consensus was based on economic openness aimed at fostering international trade between developing and developed countries as a vehicle for economic growth. Reduced government intervention brought increased social tensions due to the reduction of subsidies and incomplete compensation programmes, which in some cases resulted in social unrest episodes.

During the early 21st century, multiple South American governments initiated a shift in orientation essentially representing a departure from the neoliberal model, with regional agendas differing from those aligned to the consensus. From the 2000's onwards, regionalism starts to claim a simultaneous economic and political dimension, also allowing 
for a more active government role in managing globalisation challenges. Social aspects become a key component in line with social development objectives (e.g. UN's Millennium Objectives). This development occurs in line with reconsideration of the role of the state and the extent of its reach (Bizzozero, 2011a; Świerczyńska, 2017).

Tokatlian (2012) describes that South America suffers from an 'integration complex' with ambiguous results in a region representing a heterogeneous unity, particularly when referring to the political direction within countries. This characteristic is reflected in the existence of multiple blocs and trade agreements evolving simultaneously in a changing political landscape (Ulloa Urrutia \& Marambio, 2014), highlighting that integration ideas are deeply ingrained, assuming that all countries in the region are involved in at least one integration initiative (Rhi-Sausi \& Oddone, 2013).

Currently, the main active trade blocs with relevant presence of South American countries are the Southern Common Market (Mercosur) formed in 1991 and currently with five full members: Argentina, Brazil, Paraguay, Uruguay and Venezuela; the Pacific Alliance (PA) formed in 2011 and currently with four full members: Chile, Colombia, Mexico and Peru; the Andean Community of Nations (ACN) formed in 1969 and currently with four full members: Bolivia, Colombia, Ecuador and Peru; and the Bolivarian Alliance for the Peoples of Our America (ALBA) formed in 2004 and currently with eleven countries as full members: Antigua and Barbuda, Bolivia, Cuba, Dominica, Ecuador, Grenada, Nicaragua, Saint Kitts and Nevis, Saint Lucia, Saint Vincent and the Grenadines and Venezuela ${ }^{1}$.

From this group, Mercosur and the Pacific Alliance are of particular relevance, given that they represent the two largest in terms of the size of their economies. Based on International Monetary Fund data ${ }^{2}$, for 2017 Mercosur represented approximately $3.7 \%$ of the world's GDP and the PA 3.2\%, whereas the ACN accounted for $1.1 \%$ and ALBA for $0.6 \%$. The Spanish language expert database is built with focus primarily on Chile, although expanded to South American nations participating in the above listed agreements (i.e. Argentina, Brazil ${ }^{3}$, Paraguay, Uruguay, Venezuela, Colombia, Peru, Bolivia and Ecuador).

In terms of the nature of the main agreements, Mercosur is designed as a free trade zone and customs union, and even though it was established in 1991, progress towards full implementation has been slow. Moreover, it serves as an example of the effects of an on-going political change in economic policy and trade relations within a major trade bloc, and of the potential evolution of trade blocs towards more open arrangements (i.e. fomenting bloc relations with non-bloc parties). On the other hand, the Pacific Alliance, a newer initiative started in 2011, represents a new pragmatic approach in which economic aspects are not secondary to political considerations. Furthermore, the PA constitutes an agreement where the relation of the block with third parties are as important as

\footnotetext{
${ }^{1}$ Additional regional blocs could be mentioned, such as the Community of Latin American and Caribbean States (CELAC) and the Union of South American Nations (UNASUR), although these are by conception primarily political organisations rather than trade blocs. There are other trade blocs in the Latin American region, being the most important the North American Free Trade Agreement (NAFTA), although, this agreement is beyond the scope of the analysis, given that it does not include any South American nations.

2 The data considers only full members, as those represent the countries having fully adopted the agreement. However, it must me mentioned that each of these agreements incorporate associated or observer countries. The percentage corresponds to the Gross domestic product based on purchasing-power-parity (PPP) share of world in total as indicated in the IMF's World Economic Outlook (October 2017).

${ }^{3}$ Literature review is limited to documents published in the Spanish language.
} 
intra-bloc relations. Therefore, it represents a new model of a trade agreement and integration structure, and as such it is of key importance as a potential marker for the evolution of these type of initiatives in the region and beyond.

The 2011-2017 period is of particular relevance in terms of events determining the current and potential future situation for the trade agreements in which South American countries partake. One particular event occurred in 2011 with the undertaking of foundational steps towards the creation of the Pacific Alliance, representing a more mature strategy with increased alignment between commercial and political interests (Rojas \& Terán, 2016). A second event was the restructuring of both Mercosur and Andean Community starting in 2011 with Venezuela effectively leaving the ACN for incorporation into Mercosur, an event also serving to exemplify the prevalence of political interest over economic integration (Gutierrez, 2013), a phenomenon visible in earlier-generation agreements.

\section{Regional Public Opinion on Integration}

At present, regional integration can be seen as an incomplete project, with limitations such as reduced intraregional trade, lack of coordination, and the existence of multiple simultaneous integration attempts following different approaches and ideological perspectives (Bárcena, Prado, Rosales, \& Pérez, 2014; Bruslé, 2015; Benešová, Novotná, Šánová, \& Laputková, 2016). Optimising and integrating the multiple initiatives that have been developed over the last 60 years, involving tens of agreements and over 15 national associations with a variety of supranational bureaucratic structures is imperative (Foxley, 2015). Nevertheless, the reality is that political interests can disrupt long term advances in commercial aspects, as has been seen within Mercosur or with the clash of ideas between the ACN and the ALBA, where political adherences have recently been the sole determinant of economic policy (Giacalone, 2013), and through the critical views over the PA due to being an economic minded agreement among pro-market governments (Nolte \& Wehner, 2014).

Traditionally, at relatively early integration stages, innovative organisational arrangements have been greatly valued, even despite the absence of major results (Bizzozero, 2011b). In contrast, decades after the conception, the agreement is evaluated from a more critical perspective, as recent public opinion commonly focuses on the lack of consistency between promises and reality, as well as institutional inefficiencies, even if some degree of social and political improvements are a reality (Caballero Santos, 2014).

Within the South American context, the implementation of social policies towards welfare increases is identified as the key political consideration and trade is seen as an active tool towards this objective. Latinobarómetro Corporation, a private non-profit organisation, based in Chile, is responsible for carrying out Latinobarómetro's public opinion surveys providing a regional view on multiple topics, including current regional integration profile.

Over time, public views on economic and political opinions can and do change, both as a political change catalyst and as a social reaction to policy measures or international environment. Latinobarómetro has performed multiple public opinion surveys from 1995 to $2017^{4}$, therefore allowing to review the public opinion evolution on a variety of aspects. In 1995, 74\% of the surveyed supported an economic system based on private enterprises with varying degrees of government intervention, and only $11 \%$ supported the notion of

\footnotetext{
${ }^{4}$ Latinobarómetro annual public opinion surveys from 1995, 2000, 2005, 2010, 2015 and 2017.
} 
no government intervention, which can be consistent with early reactions to the application of Washington Consensus-based measures in the absence of efficient social compensation efforts. When evaluating the situation in 2005 (at the early stages of new post Washington Consensus) one may observe that there is, however, a general support for a market economy although combined with well-expressed social sentiments for government intervention (63\% of the population is in favour). At the same time, public opinion on the efficiency of recently privatised public services is not positive (with $58 \%$ of the population displaying dissatisfaction with the post-privatisation situation).

At this point, it is of key importance to assess public views on integration within the region during the period, which could be summarised in Table 1.

Table 1. Public opinion on regional economic integration

\begin{tabular}{|l|c|c|c|c|}
\hline \multicolumn{1}{|c|}{ Public opinion } & $\mathbf{1 9 9 5}$ & $\mathbf{2 0 0 5}$ & $\mathbf{2 0 1 0}$ & $\mathbf{2 0 1 7}$ \\
\hline In favour of economic integration & $64 \%$ & $65 \%$ & $65 \%$ & $\mathbf{7 7 \%}$ \\
\hline Against economic integration & $17 \%$ & $21 \%$ & $12 \%$ & $16 \%$ \\
\hline
\end{tabular}

Source: Latinobarómetro annual public opinion surveys from 1995, 2005, 2010 and 2017 available at www.latinobarometro.org and consulted on 15 August 2018.

It should not be so surprising that in the 90 s and the period before the global financial crisis more than half of the population believed that belonging to integrated economic blocs or being engaged in FTAs is beneficial, with much less than one fifth disagreeing with this view. However, it is interesting to see that such a high level of support was maintained after the crisis outburst and it grew up in more recent times. It seems that a desire for free access to goods and services within the region still exists (is getting stronger) and is deeply ingrained in the South American public psyche, even if 'the integration project' is lacking its feasibility in economic, political and social spheres (Bermúdez Torres, 2011). An increase in public support for economic integration may also result from positive macroeconomic performance of some regional economies, and thus an increase in social wealth. Moreover, the development of the PA, TTP negotiations and revamping of Mercosur in line with political changes in some countries may have played its role. Interestingly, support for political integration increased, as well as the proportion of those against it, which can be explained by a lower number of non-respondents but also attributable to the desire for a more mature institutional framework, in other words, advancing in closing the gap between de facto and de jure realities.

Consistently, in 2017, 77\% of respondents supported other (in the region) countries' free access to goods and services in the region, and $88 \%$ of the surveyed population was for workers' free access to other regional markets. This positive view is consistent with the wider opinion of 4 out of 5 inhabitants that globalisation brings opportunities for economic growth. Furthermore, the majority of the population identified free trade as a key component to integration, which is aligned with acknowledging integration (and subsequent trade) as a tool for social welfare improvements.

At the same time, social policies (including poverty reduction) were seen among most relevant factors for national development in 2017 (mentioned by $49 \%$ of respondents). Integration per se (mentioned by $25 \%$ of respondents) was ranked well behind a variety of different categories defined as relevant, such as: environment (48\%), infrastructure (40\%), public institutions (34\%), rule of law (38\%), gender equality (34\%), equal opportunities 
(46\%), productivity (37\%) and human capital (27\%). This can suggest that integration is not perceived as a (practical?) goal in itself but probably rather broadly contextualised, perceived as a positive process, somehow contributing to social progress. Interestingly, people do appreciate successful integration implicite, recognizing the importance of its components, to mention only physical infrastructure, public institutions and rule of law among them. That goes in line with $66 \%$ of regional inhabitants declaring themselves as dissatisfied with their national institutions, which also occurs with supranational ones.

When evaluating preferences in terms of which regions were seen as more important for deepening economic integration, it should be highlighted that the United States was named by $34 \%$ of the respondents, while Latin America as a region ranked close to the European Union, China and Japan (all of these ranging from $11 \%$ to $16 \%$ ). The relative unimportance of the home region can be explained by the current lack of maturity in on-going integration initiatives (together with the existence of multilateral agreements), resulting in diminished effects and overall efficiency. On the other hand, the prevalence of the United States as the identified relevant economic integration partner can be associated with the positive views on the effects of incoming foreign investment flows, which is supported by $67 \%$ of the population (with only $12 \%$ against it), and this view has not changed since 1995 , where $69 \%$ of the surveyed identified direct incoming investing flows as positive.

For 1995 and 2000,19\% and $16 \%$ of the surveyed had pessimistic views over whether strong integration ties (i.e. regional common economic areas) could be a realistic goal of their governments' activities that would have been conducted by 2005, while $53 \%$ and $50 \%$, respectively, were positive on that outcome. Two decades later, when asked about it in 2017, $28 \%$ of the population strongly acknowledged their national governments' efforts towards regional integration, $32 \%$ considered that little to no efforts had been implemented within the last five years, which helps to illustrate the perceived stagnated current state affairs and limited trust of the public in the governments' abilities to achieve fuller integration.

The relevance of trade as a key driver of economic integration remains an important topic of public discussion. For example, despite its limitations, Mercosur was identified by the general population of Argentina, Bolivia, Brazil, Chile, Paraguay, Uruguay and Venezuela as a top multilateral organisation providing the biggest benefits for its member societies. Mercosur is also identified as the most relevant institution fostering economic development by the inhabitants of Mercosur countries, being named by $29 \%$ of respondents as crucial for development over an average response of $25 \%$ for integration as a whole.

As such, it can be said that there is demand for regional integration in Latin America and although there has been some progress, it is an incomplete process with differentiated results between countries. This phenomenon can be measured in Latinobarómetro's 'Integrometer', which is an indicator created by the Latinobarómetro NGO aiming to present a metric which measures dissatisfied demand for regional integration by quantifying it as the intersection of those respondents strongly in favour of integration while at the same time dissatisfied by their national governments' efforts (or priorities) towards integration. Basco (2017) refers to the Integrometer, highlighting that for 2017 the Latin American region metric showed an average of $7.3 \%$, more importantly, when exploring the relative metrics for South American countries, it is possible to identify that those having larger figures (i.e. Venezuela with $20.8 \%$, Argentina with $11.5 \%$ and Paraguay with $9.8 \%$ ), share comparatively 
more inefficient institutions, increased restrictions on personal freedoms, and tighter restrictions over people and capital mobility; while those with lower figures (i.e. Chile with $3.2 \%$, Ecuador with $3.3 \%$ and Brazil with $3.7 \%$ ) tend to present higher foreign trade involvement, more efficient structures, and in the Brazilian case, major size advantage. This approach allows to identify regional dynamics, while also individual advances.

To sum it up, incomplete implementation of economic integration, which is Mercosur's case, seems to be rather disappointing for the Latin American public opinion. It is also true that coexisting trade agreements are very heterogonous in their original nature. They have emerged from very different political perspectives, some initiated decades ago to concentrate on priorities that may seem a bit 'old fashioned' and fatigued now, while others were brought to life to highlight the pro-integration profile of the region, which continues to solidify despite its limitations and lack of speedy progress. Remarkably, vox populi sounds more determined and inclined to follow the economic integration path than the policy-makers' deeds. Therefore, it is quite reasonable to assume that the expert opinions could be better targeted, i.e. addressed to the latter to shed more light on economic integration, and in particular (updated) FTA anticipated results. That would, hopefully, improve social dialogue between citizens and the government, and lead to further steps in shaping a relevant economic integration model. But then again another question arises, how does 'the expert voice' sound. Is it coherent, comprehensible, and strong enough?

\section{MATERIAL AND METHODS}

\section{Expert Opinion Database in the Spanish Language}

To reflect the Spanish language 'expert opinions' concerning FTA we created a database consisting of 185 documents, which in principle included two main publishing categories:

- Spanish language research papers published in academic journals identified through international digital libraries and search resources ${ }^{5}$, as well as Chilean-based university repositories $^{6}$ (mostly located in the area of economics, but also social and political sciences).

- Economic reports or publications by Chilean-based think tanks ${ }^{7}$ with regional scope, supranational organisations $s^{8}$ and Chilean government bodies or agencies ${ }^{9}$.

Relevant key-words were applied (in Spanish): tratado de libre comercio (free trade agreement), acuerdo de libre comercio (free trade agreement), acuerdo de complementación económica (economic complementary agreement), acuerdo de asociación económica (economic association agreement), Mercosur, Acuerdo Transpacífico de Cooperación Económica

\footnotetext{
${ }^{5}$ International: Jstor, ProQuest, EBSCO, RePEc and Google Scholar.

${ }^{6}$ The search incorporated the digital libraries from the three highest ranked Chilean universities (i.e. Universidad de Chile, Pontificia Universidad Católica de Chile, and Universidad de Concepción) as per CWTS Leiden Ranking and Webometrics.

${ }^{7} 2016$ Global Go To Think Tank Index Report by the University of Pennsylvania was employed to identify the highest ranked Chilean-based think tanks. The selected organisations were Centro de Estudios Públicos, Libertad y Desarrollo, Fundación para el Progreso, Fundación Jaime Guzmán, Fundación Chile 21, Comisión Económica para América Latina CEPAL and Corporación de Estudios para Latinoamerica.

${ }^{8}$ The United Nations Conference on Trade and Development (UNCTAD) and the Organization for Economic Cooperation and Development (OECD).

${ }^{9}$ Dirección General de Relaciones Económicas Internacionales (DIRECON), ProChile and Banco Central de Chile.
} 
(Transpacific Partnership), Alianza del Pacífico (Pacific Alliance), comercio (trade) and combined with the words: efecto (effect), impacto (impact), análisis (analysis), gravedad (gravity), equilibrio (equilibrium), and modelo (model).

Following this step, only documents published in the period between 2011 and 2017 were collected. In this way we obtained a literature sample that gave an updated postcrisis perspective.

The database contains theoretical papers as well as works based on qualitative review, statistical analysis of economic and trade data, and reports prepared by supranational and Chilean agencies or think tanks. There are also research papers counted in, which are mainly model-based empirical studies aimed at possibly precise evaluation of FTA impact. The latter category constitutes only $8 \%$ of the total database content. Well-recognised FTAs like Mercosur and PA are often discussed in the papers we explored. However, various (predominantly smaller scale) either bilateral or multilateral agreements are more popular subject areas than those bigger and better recognised (Table 2).

Table 2. Core agreement focus in Spanish language database

\begin{tabular}{|l|c|}
\hline \multicolumn{1}{|c|}{ Agreement } & Percentage \\
\hline Mercosur & $20 \%$ \\
\hline Pacific Alliance & $19 \%$ \\
\hline Trans Pacific Partnership (TTP) & $3 \%$ \\
\hline Bilateral or multilateral agreements & $44 \%$ \\
\hline Other $^{10}$ & $13 \%$ \\
\hline
\end{tabular}

Source: own study.

The papers that contain strictly quantitative approach are in minority. Only historical papers are rarer.

Table 3. Main analytical objectives in the Spanish language database

\begin{tabular}{|l|c|}
\hline \multicolumn{1}{|c|}{ Objective } & Percentage \\
\hline Measuring or commenting on the impact on the economy or society & $63 \%$ \\
\hline $\begin{array}{l}\text { Commenting on political considerations, challenges and limitations for the } \\
\text { agreements }\end{array}$ & $24 \%$ \\
\hline $\begin{array}{l}\text { Providing historical background or evolution of the multiple FTAs or integra- } \\
\text { tion initiatives }\end{array}$ & $5 \%$ \\
\hline $\begin{array}{l}\text { Empirical papers measuring impact of trade agreements on trade related } \\
\text { measures }\end{array}$ & $8 \%$ \\
\hline
\end{tabular}

Source: own study.

In our meta-analysis we relied exclusively on empirical papers that had well-specified gravity equations, and provided us with point estimates for coefficients along with its standard error or variance. The subset of the selected papers that met the criteria (Table 4).

10 UNASUR, Andean Community of Nations, ALBA, NAFTA, Transatlantic Trade and Investment Partnership. 
Table 4. Empirical research identified in the Spanish language database

\begin{tabular}{|c|c|c|c|}
\hline Author & Date & Topic & Methodology \\
\hline $\begin{array}{c}\text { De Cicco, } \\
\text { Cala, Berges }\end{array}$ & 2011 & $\begin{array}{l}\text { Determinants of } \\
\text { Argentinean trade }\end{array}$ & \begin{tabular}{|c|}
$\begin{array}{c}\text { Gravity equation estimated using panel data to evaluate } \\
\text { trade determinants in Argentina using data between } \\
1992 \text { and } 2007 \text { for Argentina and } 26 \text { other countries }\end{array}$ \\
\end{tabular} \\
\hline Avila & 2017 & $\begin{array}{l}\text { Determinants } \\
\text { of foreign trade in } \\
\text { Colombia - Partners }\end{array}$ & $\begin{array}{l}\text { Gravity equation estimated using panel data to evaluate } \\
\text { export determinants between } 2000 \text { and } 2015 \text { for Co- } \\
\text { lombia and main trade partners ( } 49 \text { countries in total) }\end{array}$ \\
\hline $\begin{array}{l}\text { Bolívar Caro, } \\
\text { Cruz García, } \\
\text { Pinto Torres }\end{array}$ & 2015 & $\begin{array}{c}\text { Determinants } \\
\text { of foreign trade in } \\
\text { Colombia - Partners } \\
\end{array}$ & $\begin{array}{c}\text { Gravity equation estimated using panel data to evaluate } \\
\text { trade determinants between } 1991 \text { and } 2012 \text { for Colom- } \\
\text { bia and } 173 \text { countries }\end{array}$ \\
\hline $\begin{array}{l}\text { Morales Ri- } \\
\text { vas, Duarte, } \\
\text { Marcia } \\
\end{array}$ & 2015 & $\begin{array}{l}\text { Impact of Nicara- } \\
\text { gua's FTAs in ex- } \\
\text { ports }\end{array}$ & $\begin{array}{c}\begin{array}{c}\text { Gravity equation estimated using panel data to evaluate } \\
\text { export determinants between } 1994 \text { and } 2013 \text { for Nica- } \\
\text { ragua and main trade partners }\end{array} \\
\end{array}$ \\
\hline Riera Duarte & 2016 & $\begin{array}{l}\text { Impact of Chile- } \\
\text { Mercosur FTA in } \\
\text { Chile's trade } \\
\end{array}$ & \begin{tabular}{|l} 
Gravity equation estimated using panel data to evaluate \\
export determinants between 1990 and 2015 for Chile, \\
Mercosur and other countries ( 181 countries in total)
\end{tabular} \\
\hline $\begin{array}{c}\text { Vásquez } \\
\text { Gonzalez, } \\
\text { Cabas Monje }\end{array}$ & 2012 & $\begin{array}{l}\text { Impact of FTAs on } \\
\text { Chilean exports }\end{array}$ & $\begin{array}{l}\text { Gravity equation estimated using panel data to evaluate } \\
\text { trade determinants for Chile and OECD countries }\end{array}$ \\
\hline $\begin{array}{l}\text { Díaz Valen- } \\
\text { cia }\end{array}$ & 2016 & $\begin{array}{l}\text { Impact of FTAs on } \\
\text { Colombia exports }\end{array}$ & $\begin{array}{c}\text { Gravity equation estimated using panel data to evaluate } \\
\text { agricultural import determinants for Colombia between } \\
1990 \text { and } 2013 \text { (Colombia and the United States) }\end{array}$ \\
\hline $\begin{array}{l}\text { Rosales, } \\
\text { Gutierrez }\end{array}$ & 2016 & $\begin{array}{l}\text { Impact of FTA on } \\
\text { Venezuela-Colom- } \\
\text { bia trade }\end{array}$ & $\begin{array}{c}\text { Gravity equation estimated using panel data to evaluate } \\
\text { trade determinants between Colombia and Venezuela } \\
\text { using data between } 1995 \text { and } 2013\end{array}$ \\
\hline
\end{tabular}

Source: own study.

\section{METHODOLOGY}

In order to analyse the impact of free trade agreements (FTA), meta-analysis of the results of the research into this subject was performed using the sample of eight Spanish Language papers. A detailed description of each research is depicted in Table 5. In our research we included models in which natural logarithm of some measure of trade was regressed on the FTA dummy variable along with other explanatory variables. Regressand is expressed in terms of natural logarithms, and concerns imports, exports intra-industry trade or trade as a whole. Due to that construction of the models if the estimated coefficient is $\beta$, countries with FTA memberships experience on average $\left(e^{\beta}-1\right) * 100$ percent more trade than countries outside the free trade area (Halvorsen \& Palmquist, 1980). Still two points need to be made about this interpretation. A positive value of the coefficient does not unequivocally testify to trade creation of FTAs, as the additional trade can be a consequence of trade diversion. Secondly, this measure suffers from endogeneity issue, because a priori one can expect that countries that trade with one another a lot are more likely to establish a free trade association. The estimation strategy follows (Viechtbauer, 2010).

In meta-analysis values of the point estimate for the FTA dummy variables were considered along with their respective standard errors. We assume that for $i=1,2, \ldots, k$ independent point estimates: 
where:

$$
y_{i}=\theta+u_{i}
$$

$y_{i}$ - denotes the observed point estimate;

$\theta$ - is the true value of the point estimate;

$u_{i}$ - is the sampling error, and $u_{i} \sim N\left(0, \sigma_{i}^{2}\right)$.

Under this assumption, the obtained coefficients are unbiased and normally distributed estimates of the true effect of FTA on trade. $\sigma_{i}^{2}-$ the sampling variances are assumed to be known.

Of course, in each of the bodies of research presented in tables, a different methodology was used - estimation method, set of control variables - as well as the analysed sample of countries and time period. This introduces heterogeneity (variability) among the true values of the regression coefficients. There are several ways one can deal with this problem. Firstly, random effects model can be applied, which is given by:

$$
\theta_{i}=\mu+v_{i}
$$

where:

$v_{i} \sim N\left(0, \tau^{2}\right)$ - in such a model structure, the true coefficient is assumed to be normally distributed with mean $\mu$ and variance $\tau^{2}$ (Viechtbauer, 2010);

$\mu$ - is the value of the true coefficient;

$\tau^{2}$ - measures the total heterogeneity among the true coefficients - with $\tau^{2}=0$ implying homogeneity.

Both random effects model provides an unconditional inference about the true value of the coefficient under consideration (Hedges \& Vevea, 1998). The k studies included in the meta-analysis are treated as a random sample taken from a hypothetical population of studies that were conducted, will be conducted or might have been conducted. So inferences taken from random and mixed effects models consider the average coefficient from the population from which studies under consideration are a random sample.

On the other hand, fixed effects models provide conditional inference, about the $\mathrm{k}$ research under consideration in the meta-analysis (Hedges \& Vevea, 1998). In other words, a fixed effects model is helpful in assessing the value of the true coefficient under consideration in the $k$ studies included in the analysis. A Fixed effects model can be applied with unweighted least squares as:

where:

$$
\bar{\theta}_{u}=\frac{\sum_{i=1}^{k} \theta_{i}}{k}
$$

$\bar{\theta}_{u}$ - is a simple average of true effects (Laird \& Mosteller, 1990). Weighted least squares estimates are given by:

$$
\bar{\theta}_{w}=\frac{\sum_{i=1}^{k} w_{i} \theta_{i}}{w_{i}},
$$

with weights given by $w_{i}=1 / v_{i}$. 
Table 5. Studies used in meta-analysis

\begin{tabular}{|c|c|c|c|c|c|c|c|}
\hline $\begin{array}{l}\text { Authors } \\
\text { (year) }\end{array}$ & $\begin{array}{l}\text { Estimated } \\
\text { coefficient }\end{array}$ & $\begin{array}{c}\text { Standard } \\
\text { error }\end{array}$ & Method & Period & $\begin{array}{c}\text { Sample of } \\
\text { countries }\end{array}$ & $\begin{array}{l}\text { Dependent } \\
\text { variable }\end{array}$ & Control variables \\
\hline $\begin{array}{l}\text { De Cicco, } \\
\text { Cala, \& } \\
\text { Berges } \\
(2011)\end{array}$ & -0.351 & 0.155 & $\begin{array}{l}\text { GLS, } \\
\text { random } \\
\text { effects }\end{array}$ & $\begin{array}{l}1992- \\
2007\end{array}$ & $\begin{array}{c}28 \text { devel- } \\
\text { oped and } \\
\text { developing } \\
\text { countries }\end{array}$ & $\begin{array}{l}\text { Intra-in- } \\
\text { dustry } \\
\text { trade }\end{array}$ & $\begin{array}{l}\text { Gravity variables, cul- } \\
\text { tural similarity, GDP } \\
\text { differential, HDI dif- } \\
\text { ferential, GDP per } \\
\text { capita, GDP per cap- } \\
\text { ita differential } \\
\end{array}$ \\
\hline \multirow{3}{*}{$\begin{array}{l}\text { Avila } \\
\text { (2017) }\end{array}$} & 0.96111 & 0.14757 & \begin{tabular}{|c|} 
Panel cor- \\
rected \\
standard \\
errors
\end{tabular} & \multirow{3}{*}{$\begin{array}{l}2000- \\
2015\end{array}$} & \multirow{3}{*}{$\begin{array}{c}49 \text { devel- } \\
\text { oped and } \\
\text { developing } \\
\text { countries }\end{array}$} & \multirow[t]{3}{*}{ Exports } & \multirow{3}{*}{$\begin{array}{l}\text { GDP differential, } \\
\text { common language, }\end{array}$} \\
\hline & 1.043884 & 0.192278 & Pooled OLS & & & & \\
\hline & 1.039231 & 0.6465436 & $\begin{array}{c}\text { Random } \\
\text { Effects OLS }\end{array}$ & & & & \\
\hline \multirow[b]{2}{*}{$\begin{array}{l}\text { Bolívar } \\
\text { Caro, Cruz } \\
\text { García, \& } \\
\text { Pinto } \\
\text { Torres } \\
\text { (2015) }\end{array}$} & 0.848 & 0.099 & Pooled OLS & & & & Area, common lan- \\
\hline & 1.473 & 0.278 & $\begin{array}{c}\text { Random } \\
\text { Effects OLS }\end{array}$ & $\begin{array}{l}1991- \\
2012\end{array}$ & $\begin{array}{c}173 \text { Coun- } \\
\text { tries }\end{array}$ & Trade & $\begin{array}{l}\text { guage, common bor- } \\
\text { der, coastline, island, } \\
\text { colonial ties, the } \\
\text { same nation, com- } \\
\text { mon currency, WTO, } \\
\text { trade preferences, oil } \\
\text { prices }\end{array}$ \\
\hline Morales & 13.2511 & 4.62723 & \multirow{4}{*}{$\begin{array}{l}\text { Fixed Ef- } \\
\text { fects OLS }\end{array}$} & \multirow{4}{*}{$\begin{array}{l}1994- \\
2013\end{array}$} & \multirow{4}{*}{$\begin{array}{c}15 \text { South } \\
\text { American } \\
\text { countries }\end{array}$} & \multirow{4}{*}{ Exports } & \multirow{4}{*}{ Gravity variables } \\
\hline \multirow{3}{*}{$\begin{array}{c}\text { Duarte, \& } \\
\text { Marcia } \\
(2015) \\
\end{array}$} & 6.79976 & 1.89074 & & & & & \\
\hline & 6.06909 & 2.22592 & & & & & \\
\hline & 10.3576 & 3.14054 & & & & & \\
\hline $\begin{array}{l}\text { Riera } \\
\text { Duarte } \\
(2016)\end{array}$ & -0.4307603 & 0.1173431 & Pooled OLS & $\begin{array}{l}1990- \\
2015\end{array}$ & $\begin{array}{c}181 \text { coun- } \\
\text { tries }\end{array}$ & Exports & \begin{tabular}{|c}
$\begin{array}{c}\text { Land, isolation level, } \\
\text { coast, common bor- } \\
\text { der, common lan- } \\
\text { guage }\end{array}$ \\
\end{tabular} \\
\hline $\begin{array}{c}\text { Vásquez } \\
\text { Gonzalez \& } \\
\text { Cabas } \\
\text { Monje } \\
(2012) \\
\end{array}$ & 0.8952 & 0.0489 & FGLS & $\begin{array}{l}1960- \\
2010\end{array}$ & $\begin{array}{c}\text { OECD } \\
\text { countries }\end{array}$ & Trade & $\begin{array}{l}\text { GDP per capita, com- } \\
\text { mon language }\end{array}$ \\
\hline $\begin{array}{l}\text { Díaz Valen- } \\
\text { cia (2016) }\end{array}$ & -6.471 & 30.848 & Pooled OLS & $\begin{array}{l}1990- \\
2013\end{array}$ & \begin{tabular}{|c|}
$\begin{array}{c}\text { Colombia, } \\
\text { United } \\
\text { States }\end{array}$ \\
\end{tabular} & Imports & Output, tariffs \\
\hline $\begin{array}{c}\text { Rosales \& } \\
\text { Gutierrez } \\
(2016) \\
\end{array}$ & 0.25 & 0.13 & Pooled OLS & $\begin{array}{l}1995- \\
2013\end{array}$ & \begin{tabular}{|c|} 
MER- \\
COSUR \\
countries \\
\end{tabular} & Trade & $\begin{array}{c}\text { Gravity variables, } \\
\text { common language, } \\
\text { common border }\end{array}$ \\
\hline
\end{tabular}

Source: own study.

The random effects models were fitted using a two stage approach (Raudenbush, 2009). In the first stage residual heterogeneity was estimated using one of the following estimators: the Hunter-Schmidt estimator (Hunter \& Schmidt, 2004) - 'HS', the Hedges estimator (Hedges \& Olkin, 1985; Raudenbush, 2009) - 'HE', the DerSimonian-Laird estimator (DerSimonian \& Laird, 1986; Raudenbush, 2009) - 'DL', the Sidik-Jonkman estimator 
(Sidik \& Jonkman, 2005a; 2005b) - 'SJ', the maximum-likelihood - 'ML' - and restricted maximum-likelihood estimator (Viechtbauer, 2005; Raudenbush, 2009) - 'REML', and the empirical Bayes estimator (Morris, 1983; Berkey et al., 1995) - 'EB'. In the second stage $\mu$, $\beta_{0}, \beta_{1}, \ldots, \beta_{7}$ were estimated using weighted least squares with weights $w_{i}=1 /\left(v_{i}+\right.$ $\left.\widehat{\tau^{2}}\right)$, where $\widehat{\tau^{2}}$ is the estimate of $\tau^{2}$. Later on, the null hypothesis of $\tau^{2}=0$ for random effects models was tested using Cochran's Q-test (Hedges \& Olkin, 1985).

Two sessions of estimations were run. In the first one, all models from all the articles were taken as a sample - in that instance, k amounted to 14 observations. In the second one the author's preferred models were chosen, and in this case, $k$ is given by eight observations. All the calculations were performed using the metafor package for R (Viechtbauer, 2010).

\section{RESULTS AND DISCUSSION}

Meta-analysis for all the Spanish language studies was conducted at the study level and at the model level. This amounted to fourteen different models, and eight different studies. The models chosen for the study level were the ones preferred by the authors of the article. Firstly, we present the results at the model level. The results of the random effects models are reported in Table 6.

It turns out that no matter which estimator is utilised the values of the obtained parameters are positive and statistically different from zero at 0.05 level. Values of the estimated parameters range from 0.692 for the Hedges estimator to 2.309 for the Sidik-Jonkman estimator. This suggests that the FTA members trade with each other more by from 111 to 906 percent. The dispersion between the results is very wide, yet still it provides strong evidence supporting the hypothesis that FTAs are facilitating trade very effectively. Still based on the data at hand, one cannot say whether this effect can be attributed to the trade creation or the trade diversion effect. The Cochrane Q-test shows that the hypothesis of homogeneity in true effects can be rejected at any conventional level.

Table 6. Results of random effects estimation for 14 models

\begin{tabular}{|c|c|c|c|c|c|c|c|c|c|}
\hline Estimator & HS & HE & DL & SJ & ML & REML & EB & MAX & MIN \\
\hline$\theta$ & 0.748 & 0.692 & 0.807 & 2.309 & 0.864 & 0.936 & 2.129 & 2.309 & 0.692 \\
\hline se $(\theta)$ & 0.172 & 0.036 & 0.205 & 1.053 & 0.235 & 0.271 & 0.903 & 1.053 & 0.036 \\
\hline$z$ & 4.351 & 19.362 & 3.939 & 2.192 & 3.673 & 3.447 & 2.358 & 19.362 & 2.192 \\
\hline$p$ & 0.000 & 0.000 & 0.000 & 0.028 & 0.000 & 0.001 & 0.018 & 0.028 & 0.000 \\
\hline $95 \%$ low & 0.411 & 0.622 & 0.405 & 0.244 & 0.403 & 0.404 & 0.360 & 0.622 & 0.244 \\
\hline $95 \%$ upp & 1.085 & 0.762 & 1.208 & 4.373 & 1.325 & 1.467 & 3.899 & 4.373 & 0.762 \\
\hline$\tau^{\wedge} 2$ & 0.229 & 0.000 & 0.340 & 12.642 & 0.464 & 0.638 & 9.031 & 12.642 & 0.000 \\
\hline$\tau$ & 0.478 & 0.000 & 0.583 & 3.556 & 0.681 & 0.799 & 3.005 & 3.556 & 0.000 \\
\hline $\mathrm{I}^{\wedge} 2$ & $90.28 \%$ & $0.00 \%$ & $93.23 \%$ & $99.81 \%$ & $94.97 \%$ & $96.29 \%$ & $99.73 \%$ & $99.8 \%$ & $0.0 \%$ \\
\hline $\mathrm{H}^{\wedge} 2$ & 10.290 & 1.000 & 14.840 & 514.980 & 19.870 & 26.940 & 368.160 & 515.0 & 1.000 \\
\hline $\mathrm{Q}$ & \multicolumn{8}{|c|}{192.885} \\
\hline $\mathrm{p}(\mathrm{Q})$ & \multicolumn{8}{|c|}{0.000} \\
\hline
\end{tabular}

Source: own study.

The results of the fixed effects model are shown in Table 7. The coefficient obtained using weighted least squares is equal to 0.69 and is highly statistically significant. The coefficient 
obtained with unweighted least squares amounts to 2.575 and it is not statistically significant at any conventional level. As the fixed effects model with unweighted least squares is nothing more than a plane average, this result paints rather a distinctive picture of an impact of FTA on trade in the Spanish language literature. On one hand, the random effects model shows that the true effect of FTA on trade is positive and highly significant. On the other, results presented in the literature are not so unequivocal, as they present both positive and negative point estimates, and in some studies, they are reported as not significant.

Table 7. Results of fixed effects estimation at the model and the study level

\begin{tabular}{|c|c|c|c|c|}
\hline LEVEL & \multicolumn{2}{|c|}{ Model } & \multicolumn{2}{c|}{ Study } \\
\hline Method & Weighted & Unweighted & Weighted & Unweighted \\
\hline$\theta$ & 0.692 & 2.5751 & 0.659 & 1.159 \\
\hline $\mathrm{se}(\theta)$ & 0.036 & 2.2497 & 0.037 & 3.899 \\
\hline $\mathrm{z}$ & 19.362 & 1.145 & 17.932 & 0.297 \\
\hline $\mathrm{p}$ & 0.000 & 0.252 & 0.000 & 0.766 \\
\hline $95 \%$ low & 0.622 & -1.834 & 0.587 & -6.484 \\
\hline $95 \%$ upp & 0.762 & 6.985 & 0.731 & 8.801 \\
\hline $\mathrm{Q}$ & \multicolumn{2}{|c|}{192.885} & \multicolumn{2}{c|}{0.000} \\
\hline $\mathrm{p}(\mathrm{Q})$ & 0.000 & \multicolumn{3}{c}{} \\
\hline
\end{tabular}

Source: own study.

Now we turn to the study level. The results for the random effects model are shown in Table 8. Here all estimated values of the FTA dummy parameter are positive, yet their significance relies upon the application of the particular estimator. Under the Sidik-Jonkman, as well as the empirical Bayes estimator the value of the parameter is not different from zero at any conventional level. At the study level, the true effect ranges from 0.442 for the HunterSchmidt estimator to 1.138 for the Sidik-Jonkman estimator. This implies that the countries inside the FTA on average trade by 56 to 211 percent more than countries outside these agreements. The $Q$ rejects the null hypothesis of homogeneity at any conventional level.

Table 8. Results of random effects estimation for 8 preferred models

\begin{tabular}{|c|c|c|c|c|c|c|c|c|c|}
\hline Estimator & HS & HE & DL & SJ & ML & REML & EB & MAX & MIN \\
\hline$\theta$ & 0.748 & 0.692 & 0.807 & 2.309 & 0.864 & 0.936 & 2.129 & 2.309 & 0.692 \\
\hline $\mathrm{se}(\theta)$ & 0.172 & 0.036 & 0.205 & 1.053 & 0.235 & 0.271 & 0.903 & 1.053 & 0.036 \\
\hline $\mathrm{z}$ & 4.351 & 19.362 & 3.939 & 2.192 & 3.673 & 3.447 & 2.358 & 19.362 & 2.192 \\
\hline $\mathrm{p}$ & 0.000 & 0.000 & 0.000 & 0.028 & 0.000 & 0.001 & 0.018 & 0.028 & 0.000 \\
\hline 95\%low & 0.411 & 0.622 & 0.405 & 0.244 & 0.403 & 0.404 & 0.360 & 0.622 & 0.244 \\
\hline $95 \%$ upp & 1.085 & 0.762 & 1.208 & 4.373 & 1.325 & 1.467 & 3.899 & 4.373 & 0.762 \\
\hline$\tau^{\wedge} 2$ & 0.229 & 0.000 & 0.340 & 12.642 & 0.464 & 0.638 & 9.031 & 12.642 & 0.000 \\
\hline$\tau$ & 0.478 & 0.000 & 0.583 & 3.556 & 0.681 & 0.799 & 3.005 & 3.556 & 0.000 \\
\hline $\mathrm{I}^{\wedge} 2$ & $90.28 \%$ & $0.00 \%$ & $93.23 \%$ & $99.81 \%$ & $94.97 \%$ & $96.29 \%$ & $99.73 \%$ & $99.8 \%$ & $0.0 \%$ \\
\hline $\mathrm{H}^{\wedge} 2$ & 10.290 & 1.000 & 14.840 & 514.980 & 19.870 & 26.940 & 368.160 & 515.0 & 1.000 \\
\hline $\mathrm{Q}$ & \multicolumn{70}{|c|}{192.885} \\
\hline $\mathrm{p}(\mathrm{Q})$ & \multicolumn{8}{|c|}{0.000} \\
\hline
\end{tabular}

Source: own study. 
Table 7 contains estimates obtained at the study level for the fixed effects models. Here the conclusion is also similar to those attained at the model level. In both cases the effect is positive, but significant only in the case of weighted least squares. One more time comparing results from fixed and random effects models shows that even though the true effect is positive and significant, the same cannot be said about the overall picture of the research into the impact of FTA on trade in the Spanish language literature.

Summarizing, the Spanish language literature gives a lot of the support to the notion that free trade agreements are associated with higher trade. Of course, due to the measure of the FTA participation considered in the present meta-analysis, the exact size effect can be brought to question. As mentioned before, with FTA dummy variable increased traded can have its sources both in trade creation and trade diversion. Also, endogeneity issue might result in overestimation of the effect, as countries that trade more are more likely to establish free trade agreements. Having this in mind, random effects models show that the underlying true effect of the participation in FTA is both positive and significant. Weighted least squares fixed effects models at both the study and the model level support this notion. Unweighted least squares models for Spanish language papers are the only ones where the positive effect of FTA is not statistically significant. Still, the analysis shows that the bulk of research brings a lot of support to the notion that FTA brings about higher trade.

\section{CONCLUSIONS}

Regional public opinion seems to be quite supportive for FTA and economic integration over the last two decades displaying an on-going pro-integration profile. Some dissatisfaction concerning inadequate policy measures aimed at increasing and enhancing integration processes can be captured in Latinobarómetro results, this is derived from policy design inconsistencies, and inefficiency in application due to diverging political realities with multiple degrees of institutional maturity, rather than critique over integration per se. Expert opinions could be quite valuable as policy guidelines. However, our Spanish language database containing expert materials has limited quantitative content that would provide policy-makers and citizens with estimations of specific FTA effects. Meta-analysis of the selected papers that meet the necessary criteria confirms positive FTA effects, which can be used as a convincing argument for further integration in South America, although more research in this area could strengthen its value as a policy support tool while simultaneously continuing to solidify the pro-integration views of the public through the facilitation of expert knowledge transfer towards the public, particularly by delivering quantifiable expected benefits. Ultimately, this would serve to align policy-makers and perspectives of society.

The main limitation of the research concerns measures of trade integration used in the research. Research utilizing meta-analysis requires comparable statistics to draw conclusions concerning examined phenomena. The requirement of comparability imposed the choice of binary variable representing participation in free trade area that is most commonly used in FTA research. At the same time the use of the variable is associated with the issues described in the methodological section. The future research should involve more comprehensive measures of the effects of participation in free trade area on growth of international trade flows. 


\section{REFERENCES}

Ávila, H. (2017). El modelo de gravedad y los determinantes del comercio entre Colombia y sus principales socios económicos. Civilizar de Empresa y Economía, 12(1), 89-121. https://doi.org/10.22518/2462909X.688

Bárcena, A., Prado, A., Rosales, O., \& Pérez, R. (2014). La Alianza del Pacífico y el MERCOSUR. Hacia la convergencia en la diversidad. Naciones Unidas Comisión Económica para América Latina y el Caribe (CEPAL).

Basco, A.I. (2017). La tecno-integración de América Latina: Instituciones, comercio exponencial y equidad en la era de los algoritmos. Inter-American Development Bank.

Benešová, I., Novotná, Z., Šánová, P., \& Laputková, A. (2016). Economic comparison of agricultural sector of eurasian countries - is there any potential for development through economic cooperation?. Agris On-line Papers in Economics and Informatics, 8(2), 19-31.

Berkey, C.S., Hoaglin, D.C., Mosteller, F., \& Colditz, G.A. (1995). A Random-Effects Regression Model for Meta-Analysis. Statistics in Medicine, 14(4), 395-411. https://doi.org/10.1002/sim.4780140406

Bermúdez Torres, C.A. (2011). La integración regional a comienzos del siglo XXI: MERCOSUR y UNASUR. Memorias. Revista Digital de Historia y Arqueología desde el Caribe, 8(14).

Bizzozero, L. (2011a). América Latina a inicios de la segunda década del siglo XXI: entre el regionalismo estratégico y la regionalización fragmentada. Revista Brasileira de Política Internacional, 54(1).

Bizzozero, L. (2011b). Aportes del MERCOSUR al regionalismo ya la teoría política de la integración regional. Una mirada desde los veinte años del proceso. Meridiano 47, 12(125), 11.

Bruslé, L.P. (2015). La integración continental sudamericana, inscripción espacial y dispositivo discursivo. Apuntes desde Bolivia, el país de contactos. Journal of Latin American Geography, 14(2), 101-127. https://doi.org/10.1353/lag.2015.0025

Caballero Santos, S. (2014). El Acuerdo TransPacífico y su efecto en América Latina/The TransPacific Partnership Agreement and its effects on Latin America. Meridiano, 47, 15(141), 59.

Caro, L.M., García, N.C., \& Torres, A.P. (2015). Modelo gravitacional del comercio internacional colombiano, 1991-2012. Economía \& Región, 26, 245-270.

Crespo Stupková, L. (2016). Global value chain in agro-export production and its socio-economic impact in Michoacán, Mexico. Agris On-line Papers in Economics and Informatics, 8(1), 25-36.

De Cicco, J.A., Calá, C.D., \& Berges, M. (2011). Determinantes nacionales del comercio intraindustrial en Argentina. Revista de Economía y Estadística, 49(2), 27-50.

DerSimonian, R., \& Laird, N. (1986). Meta-Analysis in Clinical Trials. Controlled Clinical Trials, 7(3), 177-188. https://doi.org/10.1016/0197-2456(86)90046-2

Díaz Valencia, G.A. (2017). Incidencia del Tratado de Libre Comercio con Estados Unidos en la Competitividad del Sector Agrícola Colombiano: Casos del Arroz y Maíz. Revista de Economía del Caribe, (19), 154-182.

Foxley, A. (2015). Bases para un desarrollo inclusivo. CIEPLAN.

Giacalone, R. (2013). Venezuela en Unasur: integración regional y discurso político. Desafíos, 25(1).

Gutiérrez, A. (2013). Estrategias de desarrollo divergentes: efectos sobre la integración económica entre Venezuela y Colombia. Desafíos, 25(1), 85-127.

Halvorsen, R., \& Pamlquist, R. (1980). The Interpretation of Dummy Variables in Semilogarithmic Equations. The American Economic Review, 70(3), 474-475.

Hedges, L.V., \& Olkin, I. (1985). Statistical Methods for Meta-Analysis. San Diego, CA: Academic Press. 
Hedges, L.V., \& Vevea, J.L. (1998). Fixed- and Random-Effects Models in Meta-Analysis. Psychological Methods, 3(4), 486-504. https://doi.org/10.1037/1082-989X.3.4.486

Higgins, J.P.T, \& Thompson, S.G. (2002). Quantifying Heterogeneity in a Meta-analysis. Statistics in Medicine, 23(11), 1663-1682. https://doi.org/10.1002/sim.1186

Hunter, J.E., \& Schmidt, F.L. (2004). Methods of Meta-Analysis: Correcting Error and Bias in Research Findings. 2nd edition. Newbury Park, CA: Sage.

Laird, N.L., \& Mosteller, F. (1990). Some Statistical Methods for Combining Experimental Results. International Journal of Technology Assessment in Health Care, 6(1), 5-30. https://doi.org/10.1017/S0266462300008916

Martínez Rangel, R., Garmendia, R., \& Soto, E. (2012). El Consenso de Washington: la instauración de las políticas neoliberales en América Latina. Política y Cultura, (37), 35-64.

Morales Rivas, O., Duarte, N., \& Marcia, G. (2015). Un Modelo de Gravedad Aplicado a las Exportaciones en Nicaragua. REICE Revista Electrónica de Investigación en Ciencias Económicas, 3(6), 1-13.

Morris, C.N. (1983). Parametric Empirical Bayes Inference: Theory and Applications. Journal of the American Statistical Association, 78(381), 47-55. https://doi.org/10.1080/01621459.1983.10477920

Nolte, D., \& Wehner, L. (2014). La creciente presencia de la Alianza del Pacífico en América Latina. Iberoamericana (2001-), 14(53), 173-177. https://doi.org/10.18441/ibam.14.2014.53.173-177

Raudenbush, S.W. (2009). Analyzing Effect Sizes: Random Effects Models. In H. Cooper, L.V. Hedges, J.C. Valentine (Eds.). The Handbook of Research Synthesis and Meta-Analysis (2nd edition, pp. 295-315). New York: Russell Sage Foundation.

Rhi-Sausi, J.L., \& Oddone, N. (2013). Integración regional y cooperación transfronteriza en los nuevos escenarios de América Latina. Investigación \& Desarrollo, 21(1).

Riera, P. (2016). Evaluación del Tratado de Libre Comercio entre Chile y el Mercosur Mediante un Modelo Gravitacional. Master's thesis. Santiago, Chile: Pontifical Catholic University of Chile.

Rojas, D., \& Terán, J.M. (2016). La Alianza del Pacífico: nueva muestra del regionalismo en América Latina. OASIS, (24), 69-88. https://doi.org/10.18601/16577558.n24.05

Rosales, M., \& Gutiérrez, A. (2016). Modelo Gravitacional del Comercio entre Venezuela y Colombia ¿Es Importante el Libre Comercio para aumentar el Intercambio Binacional?. La integración Económica entre Venezuela y Colombia: Evolución. Balance y Perspectivas, 99.

Shuaibu, M., \& Oladayo, P. T. (2016). Determinants of human capital development in Africa: a panel data analysis. Oeconomia Copernicana, 7(4), 523-549. https://doi.org/10.12775/OeC.2016.030

Sidik, K., \& Jonkman, J.N. (2005a). A Note on Variance Estimation in Random Effects Meta-Regression. Journal of Biopharmaceutical Statistics, 15(5), 823-838. https://doi.org/10.1081/BIP-200067915

Sidik, K., \& Jonkman, J.N. (2005b). Simple Heterogeneity Variance Estimation for Meta-Analysis. Journal of the Royal Statistical Society C, 54(2), 367-384. https://doi.org/10.1111/j.1467-9876.2005.00489.x

Świerczyńska, K. (2017). Structural transformation and economic development in the best performing sub-Saharan African states. Equilibrium. Quarterly Journal of Economics and Economic Policy, 12(4), 547-571. https://doi.org/10.24136/eq.v12i4.29

Thoene, U., Zamora, C., Júnior, E., \& Londoño, M.C. (2017). La Alianza del Pacífico y el regionalismo latinoamericano: En búsqueda de una revitalización autonomista de la integración. Análisis Político, 30(89), 91-110. https://doi.org/10.15446/anpol.v30n89.66219

Tokatlian, J. (2012). Latinoamérica y el complejo integracionista: Un Concepto a Debate. Desarrollo Económico, 51, (204), 475-492.

Ulloa Urrutia, A., \& Marambio, S. (2014). Latinoamérica y el Caribe, desafíos comerciales de la región y una agenda para la integración Contenido. Latinoamérica. 
Vásquez González, B.A., \& Cabas Monje, J.H. (2012). Análisis De Las Exportaciones De Chile, A Los Países De La Ocde, Mediante EI Modelo Gravitacional. Proceedings del XXVIII Encuentro Nacional de Facultades de Administración y Economía, ENEFA Proceedings - Vol. 5, 2012 ASFAE.

Viechtbauer, W. (2005). Bias and Efficiency of Meta-Analytic Variance Estimators in the RandomEffects Model. Journal of Educational and Behavioral Statistics, 30(3), 261-293. https://doi.org/10.3102/10769986030003261

Viechtbauer, W. (2010). Conducting Meta-Analyses in R with the metaphor Package. Journal of Statistical Software, 36(3), 1-48. https://doi.org/10.18637/jss.v036.i03

World Trade Organization and World Bank. (2015). La función del comercio en la eliminación de la pobreza. Geneve: World Trade Organization. 


\section{Authors}

The contribution share of authors is equal and amounted to $33.33 \%$ each of them.

\section{Krzysztof Beck}

Assistant Professor, director of the Econometrics Department. Graduated from Cracow University of Economics and received PhD degree in Economics at Faculty of International Business and Economics at Poznan University of Business and Economics. A recipient of an award in the Central Statistical Office of Poland's competition for the best doctoral dissertation in Statistics. Since 2014, has been the head of Applied Economics Institute at Lazarski University in Warsaw. A lecturer on English-language double degree studies accredited by Coventry University. His main interests include: international economics, international business cycles, international trade, currency unions, macroeconomics, econometrics, applied econometrics, mathematical economics, bayesian statistics, and programming.

Correspondence to: Dr. Krzysztof Beck, Lazarski University in Warsaw, ul Świeradowska 43, 02662 Warszawa, Poland, e-mail: beckkrzysztof@gmail.com

ORCID @ http://orcid.org/0000-0003-3679-2962

\section{Bogna Gawrońska-Nowak}

Associate Professor. Graduated from the University of Lodz, Coimbra University, Erasmus University in Rotterdam and London School of Economics. She did her PhD in Economics at Faculty of Economics and Sociology at the University of Lodz and her habilitation at the Faculty of International Business and Economics at Poznan University of Business and Economics. Since 2009, she has been the head of Department of Economics at Lazarski University in Warsaw. She is a lecturer on English-language double degree studies accredited by Coventry University.

Correspondence to: Prof. UŁa, dr hab. Bogna Gawronska-Nowak, Lazarski University in Warsaw, ul Świeradowska 43, 02-662 Warszawa, Poland, e-mail: b.gawronska@lazarski.edu.pl

ORCID (1) http://orcid.org/0000-0003-3651-7637

\section{Paul Valdivieso}

A business economist and a consultant. Graduated from Andrés Bello Catholic University, University of Wales and Warsaw University of Technology Business School. He completed his PhD in Economics at Kozminski University in Warsaw. At present, he works in an international consulting firm, advising multinational groups with the financial planning of cross-border intra-group transactions. He worked at the Department of Economics at Lazarski University in Warsaw as a lecturer, and currently is a member of the Institute of Socio-Economic Enquiry in Warsaw and acts as a master's thesis supervisor within the Faculty of Economics and Business at University of Chile in Santiago. He has published articles in international and financial economics as well as strategic management.

Correspondence to: Dr. Paul Valdivieso, ISEE Instyt Społeczno-Ekonomicznych Ekspertyz w Warszawie, ul. Mickiewicza 74 lok. 74, 01-650 Warszawa, Poland, e-mail: pvaldg@gmail.com

\section{Acknowledgements and Financial Disclosure}

This article has been presented as the academic paper at the scientific conference GLOB2018: "Globalization and Regionalization in the Contemporary World: Competitiveness, Development, Sustainability" organized in Kraków on 21-22 September 2019. 


\section{Copyright and License}

(9) (1) $\Theta$

This article is published under the terms of the Creative Commons

Attribution - NoDerivs (CC BY-ND 4.0) License

http://creativecommons.org/licenses/by-nd/4.0/

Published by the Centre for Strategic and International Entrepreneurship - Krakow, Poland

The copyediting and proofreading of articles in English is financed in the framework of the Republic of Poland committed to activities aimed at science promotion.

This publication has been co-financed by the European Commission Representation in Poland. The European Commission, or any person acting on its behalf, is not responsible for the use of the information contained in this publication. This publication Commission reflects the views only of the authors, and the European Commission cannot be held responsible for any use which may be made of the information contained therein. 